\title{
PATRIARCHY AND THE “OTHER" IN THE WESTERN IMAGINATION: HONOUR KILLINGS AND VIOLENCE AGAINST WOMEN
}

\section{Kelly Amanda Train}

\begin{abstract}
The purpose of this article is to explore the pedagogical challenges of teaching university-level, feminist, anti-racist courses that examine how Eurocentric patriarchal practices of male violence against women within Canadian society are normalized and obscured through the concept of honour killing. I argue that the normalization of Western structures and practices of patriarchy reproduces racism, sexism, and classism by focusing attention on the "Otherness" of nonWestern forms of patriarchy. Honour killings are rendered as distinct from other forms of male violence against women on the basis that they are seen solely as a product of non-Western cultures and religions and not as part of a spectrum of forms of male violence against women practised by all patriarchal societies in Western and non-Western countries.
\end{abstract}

Keywords: woman abuse, honour killings, male violence, otherness, patriarchy, Eurocentrism

Kelly Amanda Train PhD is Contract Lecturer in the Department of Sociology, Ryerson University, 350 Victoria Street, Toronto, ON, M5B 2K3. Email: ktrain@,ryerson.ca 
Over the last 20 years, I have taught a sociology course on family violence at a large university in the heart of downtown Toronto, Canada. The university's student body is ethnoculturally and racially diverse, consisting of new and first-generation immigrants from multiple ethnic, racialized minority, and religious backgrounds; a small number of Indigenous students; and some White ethnic minority students who are second and third generation Canadians, as well as White students of Anglo-Saxon Christian background whose families have lived in Canada for three generations or more. Yet each time I have taught this course, my male, female, trans, and non-binary students, whether Canadian-born or of non-Western origin, have often assumed that non-Western cultures are "more patriarchal" than Western ones. Students of all ethnicities and religions (including female Muslim students) use the examples of "honour killing" — the murder of a female family member to restore the family's honour - and other non-Western patriarchal practices to "prove" this point, making the claim that the West is less oppressive and abusive of women and therefore less patriarchal than "Other" cultures.

I am interested in how White Canadian students come to see the so-called "ethnic" forms of male violence as culturally specific - as products of culture rather than patriarchy — and do not see themselves or their own experiences of male violence as implicated within this framework. I am also interested in how female students of colour, in particular those of non-Western origin and, above all, those from Islamic backgrounds, look at the patriarchal practices of Islamic cultures as fundamentally different from - "more patriarchal" than - those of the West.

Until it is pointed out to them, White female students tend not to make the connection between patriarchal practices and the male violence that is part of their everyday experience. Instead, Western forms of male violence against women are regarded as individual acts, as instances of specific men's behaviour. Violent and aggressive male behaviour towards women is often excused as "rational" or "legitimate", and women often blame themselves for doing or not doing something that creates a situation that leads to male violence against them (Fong, 2010a). Michael Kaufman (1987) asserted that male violence against women is an expression of male domination. bell hooks (1984) argued that male violence and domination of women is rooted in larger Western philosophical beliefs of hierarchal rule and linked to all acts of violence between the powerful and the powerless. She further asserted that men are likelier than women to perpetrate violence as they have greater social, political, economic, and legal power.

Western patriarchal forms of violence against women may go unnoticed or unrecognized as male violence. Verbal, emotional, psychological, and financial violence can be unmarked and invisible, but they are embedded in Western cultural forms of male violence that are part of normalized and expected male behaviour through Western hegemonic masculinity. Often, students do not recognize non-physical forms of male violence as male violence at all. Even when they do, it is again seen as the particular behaviour of individual men. In contrast, verbal, emotional, psychological, and financial, as well as physical, violence perpetrated within Muslim families and 
communities is viewed as primarily a problem of Islamic cultures, and not of patriarchy or as occurring on the wider spectrum of male violence against women. As Anna Korteweg (2014) argued, honour killings become a sign of "immigrant backwardness" rather than being understood as one of the many forms of family violence.

This paper is an initial exploration of the research questions: How do we look at specific examples or particularized contexts and recognize that honour killings occur on a spectrum of male violence against women without falling into dominant or hegemonic, Orientalist, imperialist, or racist discourses? How can we frame a discussion about cultural specificities of male violence against women without resorting to problematic racist discourses? How do we unpack and deessentialize the concept of culture? How do we understand patriarchy as culture and not as separate from culture?

My pedagogical approach is to develop critical knowledges in students' minds towards family violence, so that they come to understand that difference is not simply a benign fact but a phenomenon that must be understood as an outcome of historical processes of conflict, struggle, and power relations comprising both domination and resistance (Mohanty, 1994). The challenge is to get students to recognize that women of colour are not a homogeneous group who have been victimized by their traditions, cultures, and religions, but rather are subjects of various struggles in history that have been shaped by the relationship of cultural imperialism, culture, and patriarchy (Mohanty, 1994). The pedagogical challenge also involves bringing students to acknowledge a more nuanced understanding of how violence against women in Western societies reflects historical processes of Eurocentric patriarchal practices that have shaped male violence against women in the West as systemic rather than individual.

I argue that the normalization of Western structures and practices of patriarchy reproduces racism, sexism, and classism by focusing attention on the "Otherness" of non-Western forms of patriarchy, thereby creating an "us" versus "them" dichotomy in which non-Western patriarchal practices are considered a product of "culture", while Western forms of patriarchy are considered to be devoid of "culture". Honour killings are rendered as distinct from other forms of male violence against women: they are seen solely as a product of non-Western cultures and religions and not as part of the universal spectrum of male violence against women. Instead, Western legal institutions are seen as promoting a just society that guards against the acceptance of woman abuse. Non-Western forms of woman abuse are presented as "barbaric cultural practices" of traditional societies in opposition to the so-called neutral and objective or "culture-free" Western judicial institutions and laws (Korteweg, 2014). This article attempts to unpack and challenge how the Western gaze represents the cultural particularization of male violence against women through honour killings as a symbol of Muslim Otherness. It highlights how discussions of honour killings need to take into account the larger context of male violence against women. 
International Journal of Child, Youth and Family Studies (2021) 12(1): 143-157

\section{Defining Male Violence Against Women}

Within the legal systems of Western societies, family violence is typically prosecuted under general laws governing violence and abuse (Department of Justice, n.d.). Such prosecutions are usually limited to violence that is easily recognizable and intelligible within a framework of "evidence" and "proof" - in other words, violence that can be verified through its physical manifestations. The collection of statistics regarding family violence in the West revolves around charges laid in cases where there are physical manifestations of abuse or where a physical assault is witnessed by police or other observers.

In all patriarchal societies, including the West, non-physical forms of male violence against intimate female partners are pervasive: verbal, emotional, psychological, spiritual, and financial forms of violence, as well as criminal harassment and stalking (Canadian Women's Foundation, 2018). Western women often do not recognize these non-physical forms of male violence against women as violence; instead, they rationalize and internalize them as patriarchal practices.

Traditionally, the gender socialization of girls and women within all patriarchal societies required women to adhere to the social construction of femininity and be passive and submissive to male authority and men in general. Over the last fifty years, this has begun to evolve in the direction of greater equity. Nonetheless, the continuing association of women with the private sphere means that women are socially constructed as responsible for not only the physical performance of domestic labour, child care, and elder care, but also for the emotional work of creating and maintaining a peaceful and harmonious atmosphere in the home (Armstrong \& Armstrong, 2010). Women internalize these expectations, and therefore feel it is part of their gendered role to quell male aggressions by creating a tranquil home environment (Armstrong \& Armstrong, 2010; Fong 2010a). When that fails, they blame themselves, or are blamed by others — extended family members, friends, neighbours, or the public at large (Fong, 2010a, 2010b).

Physical violence against women perpetrated by Western men is viewed as the aberrant behaviour of those particular men (Fong, 2010b). Yet when violence against women, whether physical or non-physical, is perpetrated by Muslim men, it is viewed in the Western imagination as the product of a violent culture (Islam) that embraces "barbaric" cultural practices (Korteweg, 2014). Thus, honour killings and other forms of shame-related violence are not viewed as part of the spectrum of male violence against women. Moreover, male violence against women in immigrant communities or from Muslim cultures tends to be overreported in the media, as discussed in the works of Abu-Lughod (2013), Jiwani (2010). and Razack (2008); such reports reinforce an "us" and "them" divide where the West is produced as a "civilized" culture based on law and Muslim cultures are produced as "barbaric". The concept of "honour killings" is used both in the West and abroad to reify the racialization and stigmatization of Muslim communities as inherently violent and abusive towards women (Korteweg, 2014). This binary essentialist construction of culture allows the patriarchal structures embedded in Western cultures to be obscured, and Canadians to feel morally superior, especially when this image is reinforced through 
the racist notion of Canadian institutions and organizations "saving" Muslim women from the "barbarism" of their own cultures (Razack, 1998).

Honour-related violence can take complex and multiple forms, ranging from spreading rumours (substantiated or not) about the behaviour of women in the family (e.g., their sexual "impropriety"), to various forms of domestic and family violence, forced marriage, and "honour killings" (Korteweg, 2014). Honour-related violence operates within a gendered hierarchy of seniority: elders, both men and women, are involved in planning the process of restoring a family's honour; however, it is usually a younger male who is charged with the duty of performing this violence (Korteweg, 2014).

The murders of women by male partners or ex-partners in Western families are given less attention in the media than honour killings, and are often normalized or treated as aberrations specific to particular males. Sometimes, as in honour killings, these murders of Western women are planned. For example, the abuser who expects that his wife will try to leave may purchase a weapon with the intention of using it to kill her if she does so. According to the Canadian Women's Foundation (2018), "Rates of [police-reported] violence against women vary widely across Canada" (p. 2). At the same time, based on statistical data regarding police-reported woman abuse, there are specific groups of women that tend to be at greater risk of violence, including Indigenous women, younger women between the ages of 15 and 24, women with disabilities, and ethnocultural minority women (Burczycka, 2018; Conroy, 2019; Women and Gender Equality Canada, 2020). Immigrant women are less likely to report their experiences of physical and sexual violence to the police (Canadian Women's Foundation, 2018, p. 7). These women tend to be economically dependent on their abusers, to lack the language skills necessary to report the violence, and to lack knowledge of the community services available to help them do so; as well, they may fear revictimization and possible deportation (Canadian Women's Foundation, 2018, p. 7).

For immigrant families, the processes of immigration and settlement create conditions of social and economic upheaval that make woman abuse more likely. It is not unusual for immigrants to lose their accustomed social and economic status in the community as their foreign credentials are no longer recognized after immigration. For some immigrant families, financial survival depends on wives gaining employment outside the family and community. This change in the family dynamic may result in men feeling a loss of patriarchal power and a diminished sense of masculinity, facilitating a rise in domestic violence (Korteweg, 2014). Because "honour-related" gendered violence is seen as embedded in non-Western cultures, the family violence created in immigrant families from the instability of immigration processes becomes confused with it. In Western families, when economic downturns and unemployment result in significant increases in domestic violence cases (Canadian Women's Foundation, 2018, p. 3), including those associated most recently with the COVID-19 pandemic (Allen \& Jaffray, 2020; Statistics Canada, 2020), the violence is often seen as individualized or legitimized and is not recognized as embedded in Western patriarchal cultural practices and processes. 
International Journal of Child, Youth and Family Studies (2021) 12(1): 143-157

There were approximately 73,400 cases of woman abuse reported to police in Canada in 2016 (Burczycka, 2016), and approximately 78,852 cases of police-reported woman abuse in Canada in 2018 (Burczycka, 2018). In 2009, Statistics Canada estimated that fewer than $22 \%$ of intimate partner abuse cases were reported; the vast majority were not. According to a Statistics Canada report, the rate of police-reported intimate partner violence fell by $12 \%$ between 2009 and 2018 (Burczycka, 2018). However, it must be kept in mind that the rate of domestic violence is believed to be much higher than official case counts indicate; in 2014, an estimated $70 \%$ of spousal violence was not reported to the police (Statistics Canada, 2016). In over $80 \%$ of cases of spousal abuse and intimate partner violence, women were the victims of men (Burczycka, 2018). Similarly, in 2014, 7 out of 10 people who experienced family violence were women and girls (Statistics Canada, 2016). Avakame and Fyfe (2001, as cited in Fong, 2010b) noted that when women of colour report abuse, their experiences are taken less seriously by authorities.

\section{The Cultural Particularization of Male Violence Against Women}

Culture is not monolithic or essentialist. As Korteweg (2014) stated, "Culture gives meaning to practices, including practices of violence" (p. 187). We live our lives through cultural meanings, practices, and processes. All forms of violence are culturally informed, and violence experienced by the dominant groups in society becomes the normative practice to which laws and policies are designed to respond (Korteweg, 2014). The West does not view itself as "having culture" but rather as being able to be shaped and reshaped by rational laws, policies, and procedures to solve social problems. In contrast, immigrant cultures are regarded as lacking a rational basis (Razack, 1998, 2008). As Edward Said (1979) wrote, the idea of European superiority situated in opposition to the "backwardness" of Eastern societies is reproduced globally through the hegemony of European ideas. Thus, the symbol of honour killings is used to reassure Western women that Western societies have values and rights that can protect them, while Eastern societies are shaped by tradition and culture that oppresses women and encourages their abuse (Korteweg, 2014).

In the case of honour-related violence, the family's honour is embodied in the women who are the property of the family; the honour belongs to both the men and the women of the family. Honour is really about a system of morality whereby women's behaviour symbolizes the boundaries of what is acceptable and the social reputation of the family, which are rooted in patriarchal gendered power relations (Korteweg, 2014). While Westerners tend to associate honour-related violence with non-Western cultures, they find other explanations for patriarchal violence in their own society. Anna Korteweg (2014) argued that "while 'honour' might no longer be a justification for violence against women in Western countries, 'passion' is still very much alive as a cultural explanation" (p. 189). For example, in rape and sexual assault cases, defence counsel and the media often cite the woman's behaviour - what she was wearing, or what she was doing — as the basis for legitimizing patriarchal violence (Korteweg, 2014). Incidents of Western patriarchal forms of gendered violence that are viewed as crimes of "passion" are seen as individualized, and often involve victim-blaming in the process of normalizing and rationalizing Western cultural practices of male violence against women (Korteweg, 2014; see also Johnson \& 
International Journal of Child, Youth and Family Studies (2021) 12(1): 143-157

Dawson, 2011). The concept of "honour-related violence" serves to justify seeing gendered violence and femicide as inherent to non-Western cultures while obscuring Western cultural practices of gendered violence.

Discussions about honour killings that reinforce the cultural particularization of male violence and woman abuse obscure how honour killings are part of the spectrum of male violence against women. Honour killing, dowry murder, forced marriage, and female genital mutilation are all used in the Western imagination to demarcate so-called "traditional" or non-Western societies from Western societies. As Sherene Razack (1998) argued, such discourse and imagery presents the "problem" as Islam.

Central to this racist discourse has been what Razack (2008) referred to as "the imperilled Muslim woman", "the barbaric Muslim man", and "civilized" Western society; in the Western imagination, the Muslim woman is a passive, vulnerable object and the target of violence perpetrated by the barbaric and savage Muslim man. According to this discourse, the Muslim woman requires saving from her ethnic and backward culture by civilized Western society since she is viewed as vulnerable and prone to experiencing violence (Abu-Lughod, 2013). The image of the veil, especially, has come to symbolize in the Western imagination the "helpless", "passive", and "oppressed" Muslim woman (Jiwani, 2010; Razack, 1998). Both Jiwani (2010) and Razack (1998) pointed out that the images of the veil and the niqab not only can be used to promote Western superiority, but also operate as symbols to remind Western women that they are less oppressed than their Eastern counterparts. These images are also used to mask Western patriarchal forms of woman abuse, domestic violence, and the killings that sometimes result, and to obscure how "honour killings" are part of the spectrum of male violence against women that is embedded in all patriarchal cultures, Western and Eastern.

For example, I have often encountered the claim from Western students that, although Western women are subject to physical and sexual violence in relationships, it is usually specific to a particular man, and not due either to all Western men or to patriarchy in Western culture. Western female students often argue that they are less oppressed than their non-Western peers and that Western society is less patriarchal because they are free to choose what to wear and how to express themselves and their sexuality through their clothing and their actions. In return, I will ask the class: What happens when Western women express their sexuality and wear "revealing" clothes? What happens when Western women act in ways that express their sexuality? Are verbal shaming, belittling, name-calling, rape, physical assault, and honour killings not all part of the same spectrum of male violence against women? When Western women challenge Western forms of hegemonic masculinity by violating so-called "acceptable" forms of female modesty and sexuality in these ways, are they not subject to male violence in diverse ways?

Racist discourses and imagery surrounding Western superiority also cannot help but influence Islamic female students to regard their own lived experiences within their families and communities as fundamentally different, because of their Islamic culture, from those of their 
Western counterparts. At the same time, the image of the West as being less oppressive of women is also absorbed by Muslim students. In one of my classes recently, a female Muslim student argued that, under Islamic law, the role of the husband is to be the protector and authority in the household, while the role of the wife is to be the homemaker, obedient to her husband. The student further argued that under these principles of Sharia law, the husband legally has the right to beat his wife for transgressions of his authority, and to participate in killings of female relatives for damaging the honour of the family. In the student's mind, this was an example of how male violence against women is intrinsic to Islamic culture. Yet there are multiple interpretations of the Quran and Sharia law that clearly argue that husbands do not have the right to beat or kill their wives (Ahmed, 1992).

My interest is in getting the students to think about how male violence against women is not specific to a particular religious or ethnic cultural group, but rather is differentially expressed in multiple ways in all patriarchal cultures, including the West, where it is normalized, rationalized, and obscured. I responded to the female Muslim student's argument by questioning the class about gender roles in the West. What is the role of husbands, male intimate partners, and male family members in Western families? What about the role of wives? I also asked the class about Western patriarchal marriage traditions, such as giving away the bride and taking the husband's last name, and what these traditions symbolize in terms of male ownership of women in the family. I asked my class about what Western men do when they feel that they have been undermined or had their authority challenged by their female partner, and whether Western women are allowed to react the same way towards their male partners in the same circumstances. Do traditional attitudes that continue to prevail in Western cultures assume that males have sole total control and authority over the family finances even when their female partners contribute significantly to the family economically? Although such conservative assumptions remain, these family dynamics are gradually evolving towards greater gender equality.

In asking these questions, as well as many others, I used the occasion as a pedagogical moment to draw the class's attention to how Western patriarchal practices are normalized and obscured, while "Other" non-Western patriarchal practices are viewed as barbaric and violent. After all, the concept of "honour" is based on patriarchal cultural productions of women's expected modesty, morality, and monogamy that are specific to a particular community, yet these productions are used to police and regulate women's bodies, sexuality, and behaviour in all patriarchal communities everywhere. Even so, Eurocentric ideology is so powerful that it is able to convince Western and non-Western women that Western patriarchal forms of violence simply do not exist.

Female Muslim students in my class have often accepted Eurocentric ideas that the West is "less oppressive" of women, demonstrating both the power of Eurocentric discourses and Western narratives, and the influence of their own lived experiences within their families and communities. As Sherene Razack pointed out to me (personal communication, September 21, 2013), female students from Islamic cultures see their experiences of patriarchy as culturally specific to Muslim families and communities, since that is their reality. They live their experiences of male violence 
against women through their experiences of being Muslim and through non-Western patriarchal cultural practices. It is important to note that Muslim women and girls in Canada live their everyday lives negotiating their identities and experiences between Canadian society and their immigrant families and communities.

Perhaps the racist discourses and images surrounding Muslim women are intended to "deculturalize" (Razack, 2008) and "civilize" them through forcible assimilation by the adoption of Western clothing and forgoing adherence to the Muslim faith and religious practices. In the Western imagination, Muslim women can be "saved" from their patriarchal and violent Islamic cultures through assimilation into Western society and extracting themselves entirely from Islamic culture (Razack, 2008). Even if Muslim women did elect to live outside their communities, as this concept requires, they would remain subject to racist, patriarchal, state practices. After all, Western states often fail to protect Western women from abuse, domestic violence, and the killing that sometimes results. A Muslim women who leaves her community exposes herself to greater danger from racist, sexist, state practices and policies, and cannot turn to her family and community for safety, security, and refuge from society at large.

The production of Muslim men and women as "uncivilized", albeit in different gendered forms and ways, requires the suppression of the Western colonial past. European peoples in the Western colonial past inflicted sustained violence on the original inhabitants of the colonized lands. In the Canadian context, First Nations populations bore the brunt of this violence, including their decimation from exposure to European diseases, forcible conversion to Christianity, residential schooling, impoverishment, and many other colonial and state policies of violence, some of which continue to the present day (Dyck, 1997; Frideres, 2016; Stephenson, 1999). European colonial violence was also imposed on societies throughout the East. By erasing the Western (or Canadian) colonial past, and rewriting Western (or Canadian) history, an image is created of Europeans "saving" colonized "savage" and "barbaric" peoples by bringing "civilization" to them (Lawrence, 2002; Stephenson, 1999). Against this backdrop, it is easy for the West to view male violence against women as a specifically non-Western phenomenon.

Zine (2012) wrote that the Western media discursively produces all male violence against women within Islamic families as "honour killings". For example, two cases in Canada - the murder of Aqsa Parvez and the multiple murders of women in the Shafia family — were reported in the Western media as "honour killings". Yet cases in which Western forms of woman abuse end in murder are viewed, not as manifestations of Western patriarchal culture, but as the individualized acts of particular men. Rather than understanding both the Parvez and Shafia family cases as examples of male violence against women in general, the media focused on the idea that

\footnotetext{
${ }^{1}$ Aqsa Parvez was killed in December 2007 at the age of 16 by her father, reportedly for refusing to wear the hijab (CBC News, 2010; Mitchell \& Javed, 2010). The first wife and three daughters of the Shafia family were killed by the husband/father, son, and second wife for wearing Western dress and dating (BBC News, 2018; National Post, 2018).
} 
the women were victims of Islam and their racialized minority, ethnic culture. As one news report stated of the Shafia case: "The judge said the murders were committed in the name of a "notion of honour that is founded upon the domination and control of women, a sick notion of honour that has absolutely no place in any civilized society" " (Harris, 2019, para. 6). Zine (2012) argued that, in the Western imagination, Islamic culture bears even more responsibility for the deaths of these women than the family members who carried out the crimes. By emphasizing Islamic culture, media accounts concealed the connections between the Parvez and Shafia family cases and Western patriarchal practices of male violence against women. The Western imagination sees Islam and its traditional cultural practices, not patriarchy, as responsible for these deaths.

As Abu-Lughod (2013) wrote, "honour killings" operate in the Western imagination as a comforting fantasy that empowers the West and reaffirms the belief in Western superiority for those who subscribe to it. She also pointed out that in some contexts, the category of "honour killings" allows a Westernized elite in some Muslim communities to differentiate themselves from their working class and poor counterparts in order to access new opportunities in society and gain upward social mobility.

The reality is that male violence against women is normalized and ubiquitous in all patriarchal societies regardless of religion, ethnicity, or culture. Cultures that emphasize "honour" do not have a monopoly on such violence (Abu-Lughod, 2013). Western patriarchal cultures normalize male ownership of women and their bodies, and legitimize the use of violence against women who "dishonour" them by challenging their decisions, giving attention to another male, or failing to be monogamous, even in the event of rape (Fong, 2010a, Fong, 2010b, Johnson \& Dawson, 2011). As Sherene Razack (2008) noted, the abuse and killing of Muslim women for suspected or actual "immoral" behaviour - marital infidelity, demanding a divorce, flirting, receiving phone calls from men, failing to serve a meal on time, or "allowing" herself to be raped - is viewed in the Western imagination as a type of crime rooted in the "backward" religious and cultural practices of Islam. Razack (1998) had previously argued that such crimes are no different from the abuse and killing of Western women that stem from Western patriarchal cultural practices of violence against women in intimate partner relationships, and other domestic violence.

I would argue that the regulation of women's bodies, sexuality, morality, monogamy, and modesty is central to patriarchal societies everywhere, across both Western and non-Western cultures. Abu-Lughod (2013) pointed out that families and communities in the East and West carry out the policing of women's bodies in different ways. It is a misunderstanding to view a particular type of male violence against women as specific to some communities only, and as due to culture; the complementary misunderstanding is to view male violence in other communities, most notably in the West, as a product of individual actions only, unrelated to cultural meanings or practices (Abu-Lughod, 2013).

In the classroom context, my attempts to apply and explain a more nuanced understanding of male violence against women often tend to be thwarted by systemic Eurocentrism and the 
culturalized racism of the West. White female students remain convinced that their experiences of White male violence are specific to particular White men. Both White students and students of colour, on the other hand, remain convinced that violence in Muslim families is specific and inherent to Muslim culture. In my approach to teaching family violence, I aim to develop critical knowledges that are more than an acknowledgement of and engagement in notions of difference. Rather, students must come to understand difference in a more complex manner, as a site of struggle, conflict, and resistance located in asymmetrical historical power hierarchies of Western patriarchal domination and non-Western resistance (Mohanty, 1994). To develop this approach, it is necessary that non-Western voices not be reduced to a single authoritative voice purported to speak for all non-Western women. At the same time, it is necessary to convey that Western and non-Western women share historical spaces and exist in asymmetrical power relations that shape their lives in multiple interconnected ways (Mohanty, 1994).

\section{Children, Youth, and Honour-Related Violence}

According to the 2014 General Social Survey in Canada, one third of Canadians aged 15 and over - about 10 million people — reported experiencing one or more forms of child abuse in their lifetimes, including physical or sexual abuse by an adult or witnessing violence by one parent or guardian against another adult in the home before age 15 (Burczycka \& Conroy, 2017). Although for both Western, Canadian-born children and youth and for non-Western, immigrant children and youth exposure to family violence is common, the practices implemented to help them in these situations reflect Western cultural norms only. Western institutions such as schools, social services, settlement offices, and shelters do not necessarily understand the particularities of "honour-related" gendered violence.

For instance, social workers are taught to use particular practices for dealing with family violence between parents and daughters, practices that are embedded within Western cultural norms of individual autonomy and that may be misinterpreted by immigrant parents. Calling a father to a meeting at the school to question him about why he is threatening his daughter may create a situation where the honour of the family is perceived as damaged, leading to a heightened risk of violence (Korteweg, 2014). Offering an immigrant woman or female youth space in a women's shelter may inadvertently heighten her sense that she has damaged the family honour, or that she can never return home because her family considers that she has violated their honour (Korteweg, 2014). These cases demonstrate that institutional practices and policies for dealing with male violence against women, including "honour-related" violence, do not lend themselves to a one-size-fits-all approach. Rather, such practices and policies need to be situated within the historical, social, and cultural contexts in which the violence occurs. The policies that do exist are inevitably imbued with Western cultural norms and Western family forms. 
International Journal of Child, Youth and Family Studies (2021) 12(1): 143-157

\section{Conclusion}

Culture is a dynamic process, constantly shifting and transforming. Culture is how we make sense of the world: we understand our lived experiences through our culture. Violence against women is structural, institutional, and systemic. It is embedded in all patriarchal cultures and religions. We understand and experience our lived realities of violence against women through the particular forms and practices of our cultures. These structures of violence are shaped by patriarchy, as well as by class, gender, poverty, immigration status, and state processes, together with family, community, and religious structures.

When I teach classes on family violence, I remind students that all patriarchal cultures include elements that endorse and allow for male violence against women. There is no patriarchal culture that is not oppressive of women. Different patriarchal cultures simply have different forms and ways in which male violence against women is practised, legitimized, rationalized, and allowed. Regardless, all of these forms end with the abuse and, too often, the killing of women.

I also remind students that, in the Western imagination, non-Western women are routinely depicted in racist and sexist ways. These images of non-Western women are produced through the Western media to symbolize the "helplessness" and "inferiority" of non-Western women and the "backwardness" of their non-Western cultures (Abu-Lughod, 2013; Razack, 2008; see also the Western media coverage of the Parvez and Shafia cases such as Mitchell \& Javed, 2010; CBC News, 2010; BBC News, 2018; National Post, 2018). These images simultaneously remind Western women that they are "less oppressed" than their Eastern counterparts and distract them from the fact that woman abuse and domestic violence are part of everyday experience for many. Such images dehumanize and disempower non-Western women by portraying them as helpless, vulnerable, and in need of "saving" by Western feminists. When Western feminists deny agency to non-Western women, they risk reoppressing and revictimizing those women and reproducing them as objects of racist, sexist discourse. 
International Journal of Child, Youth and Family Studies (2021) 12(1): 143-157

\section{References}

Abu-Lughod, L. (2013). Do Muslim women need saving? Harvard University Press.

Ahmed, L. (1992). Women and gender in Islam: Historical roots of a modern debate. Yale University Press.

Allen, M., \& Jaffray, B. (2020, July 30). StatCan COVID-19: Data to insights for a better Canada: The COVID-19 pandemic and its impacts on Canadian victim services [Catalogue no. 45280001]. https://www150.statcan.gc.ca/n1/en/pub/45-28-0001/2020001/article/00065eng.pdf?st=KSf7E $5 \mathrm{y}$

Armstrong, P., \& Armstrong, H. (2010). The double ghetto: Canadian women and their segregated work ( $3^{\text {rd }}$ ed.). Oxford University Press.

Avakame, E. F., \& Fyfe, J. J. (2001). Differential police treatment of male-on-female spousal violence: Additional evidence on the leniency thesis. Violence Against Women, 7(1), 22-46. doi: $10.1177 / 10778010122182280$

BBC News. (2018, March 16). Two convicted 'honour' killers to be deported from Canada. https://www.bbc.com/news/world-us-canada-43434105

Burczycka, M. (2016). Family violence in Canada: A statistical profile, 2016. Statistics Canada. https://www150.statcan.gc.ca/n1/pub/85-002-x/2018001/article/54893/03-eng.htm

Burczycka, M. (2018). Family violence in Canada: A statistical profile, 2018. Statistics Canada. https://www150.statcan.gc.ca/n1/pub/85-002-x/2019001/article/00018/02-eng.htm

Burczycka, M., \& Conroy, S. (2017). Family violence in Canada: A statistical profile, 2015. Statistics Canada. https://www150.statcan.gc.ca/n1/en/pub/85-002-x/2017001/article/14698eng.pdf? st=q2c1M2eN

Canadian Women's Foundation. (2018). Fact sheet: Moving women out of violence. https://www.canadianwomen.org/wp-content/uploads/2017/09/FactSheetVAWandDV_Feb_2018-Update.pdf

CBC News. (2010, June 16). Asqa Parvez's father, brother get life sentences. https://www.cbc.ca/news/canada/aqsa-parvez-s-father-brother-get-life-sentences-1.920103

Conroy, S. (2019). Family violence in Canada: A statistical profile, 2019. Statistics Canada. https://www150.statcan.gc.ca/n1/pub/85-002-x/2021001/article/00001/03-eng.htm

Dyck, N. (1997). Differing visions: Administering Indian residential schooling in Prince Albert 1867-1995. Fernwood Publishing. 
International Journal of Child, Youth and Family Studies (2021) 12(1): 143-157

Fong, J. (2010a). Explaining the abuse of women: An examination of conventional and dominant theoretical perspectives. In J. Fong (Ed.), Out of the shadows: Woman abuse in ethnic, immigrant, and Aboriginal communities (pp. 8-28). Women's Press.

Fong, J. (2010b). Women are still unsafe: Cracks in best practice and mandatory arrest policies. In J. Fong (Ed.), Out of the shadows: Woman abuse in ethnic, immigrant, and Aboriginal communities (pp. 58-71). Women's Press.

Frideres, J. S. (2016). First Nations peoples in Canada. Oxford University Press.

Department of Justice. (n.d.). About family violence. https://www.justice.gc.ca/eng/cj-jp/fvvf/about-apropos.html

Harris, C. (2019, December 13). Mother convicted in Shafia daughters' canal killings granted 5hour escorted absence from prison. $C B C$ News. https://www.cbc.ca/news/canada/montreal/shafia-honour-killings-tooba-yahya-parole-board$\underline{1.5396177}$

hooks, b. (1984). Feminist theory: From margin to center. South End Press.

Jiwani, Y. (2010). Doubling discourses and the veiled Other: Mediations of race and gender in Canadian media. In S. Razack, M. Smith, \& S. Thobani (Eds.), States of race: Critical race feminism for the $21^{\text {st }}$ century (Ch. 3). Between the Lines.

Johnson, H., \& Dawson, M. (2011). Violence against women in Canada: Research and policy perspectives. Oxford University Press.

Kaufman, M. (1987). The construction of masculinity and the triad of men's violence. In M. Kaufman (Ed.), Beyond patriarchy: Essays by men on pleasure, power, and change (pp. 129). Oxford University Press.

Korteweg, A. C. (2014). 'Honour killing' in the immigration context: Multiculturalism and the racialization of violence against women. Politikon, 41(2),183-208. doi: $10.1080 / 02589346.2013 .866186$

Lawrence, B. (2002). Rewriting histories of the land. In S. H. Razack (Ed.), Race, space and the law: Unmapping a White settler society (pp. 22-46). Between the Lines.

Majid, A. (1998). The politics of feminism in Islam. Signs: Journal of Women in Culture and Society, 23(2), 321-361. doi:10.1086/495253

Mernissi, F. (1993). The forgotten queens of Islam. (Mary Jo Lakehead, Trans.). University of Minnesota Press. (Original work published 1990). 
International Journal of Child, Youth and Family Studies (2021) 12(1): 143-157

Mitchell, B., \& Javed, N. (2010, June 16). 'I killed my daughter...with my hands.' The Toronto Star.

https://www.thestar.com/news/crime/2010/06/16/i_killed_my daughter_with_my hands.ht $\underline{\mathrm{ml} ? \mathrm{rf}}$

Mohanty, C. T. (1994). On race and voice: Challenges for liberal education in the 1990s. In H. A. Giroux \& P. McLaren (Eds.), Between borders: Pedagogy and the politics of cultural studies (Ch. 8). Routledge. doi:10.4324/9781315021539

National Post. (2018, March 15). Mother convicted in Shafia honour killings ordered deported but only after life sentence ends. https://nationalpost.com/news/canada/mother-convicted-ofkilling-daughters-in-honour-killing-ordered-deported

Razack, S. H. (1998). Looking White people in the eye: Gender, race, and culture in courtrooms and classrooms. University of Toronto Press.

Razack, S. H. (2008). Casting out: The eviction of Muslims from Western law \& politics. University of Toronto Press.

Said, E. (1979). Orientalism. Vintage Books, A Division of Random House.

Statistics Canada. (2009). Highlights: Family violence in Canada: A statistical profile. https://www150.statcan.gc.ca/n1/pub/85-224-x/2010000/aftertoc-aprestdm2-eng.htm

Statistics Canada. (2016). Infographic: Family Violence in Canada, 2014. https://www150.statcan.gc.ca/n1/pub/11-627-m/11-627-m2016001-eng.htm

Statistics Canada. (2020, October 20). The social and economic impacts of COVID-19: A six month update: Community safety and crime. https://www150.statcan.gc.ca/n1/pub/11-631$\underline{\mathrm{x} / 2020004 / \mathrm{s} 10 \text {-eng.htm }}$

Stephenson, W. (1999). Colonialism and First Nations women in Canada. In E. Dua \& A. Robertson (Eds.), Scratching the surface: Canadian anti-racist feminist thought (pp. 49-80). Women's Press.

Women and Gender Equality Canada. (2020). Intimate partner violence. Status of Women Canada, Government of Canada. https://cfc-swc.gc.ca/violence/knowledge-connaissance/ipvvpi-en.html

Zine, J. (2012). Unsettling the nation: Gender, race, and Muslim cultural politics in Canada. In J. Zine (Ed.), Islam in the hinterlands: Muslim cultural politics in Canada (Ch.1). University of British Columbia Press. 